\title{
Pan-PI3K Inhibitor CLR457
}

National Cancer Institute

\section{Source}

National Cancer Institute. pan-PI3K Inhibitor CLR457. NCI Thesaurus. Code C117230.

An orally bioavailable pan inhibitor of phosphatidylinositol-3-kinase (PI3K), with potential antineoplastic activity. Upon oral administration, pan-PI3K inhibitor CLR457 inhibits all of the $\mathrm{PI3K}$ kinase isoforms, which may result in apoptosis and growth inhibition in tumor cells overexpressing PI3K. Activation of the PI3K pathway promotes cell growth, survival, and resistance to both chemotherapy and radiotherapy. 